\title{
Ottochloa (Poaceae): A new generic record for Andaman and Nicobar Islands, India
}

\author{
Reshma Lakra* and Pushpa Kumari \\ Central National Herbarium, Botanical Survey of India, Botanic Garden P.O., Howrah -711103 \\ West Bengal, India \\ *Corresponding author: reshmalakra1803@gmail.com
}

\section{ऑटोक्लोआ (पोएसी) - अंडमान एवं निकोबार द्वीपसमूह के लिए एक नवीन वंशपरक अभिलेख रेशमा लकड़ा एवं पुष्पा कुमारी}

\section{सारांश}

वंश ऑटोक्लोआ डेंडी (ओ. नोडोसा (कुंथ) डेंडी),को पहली बार अंडमान एवं निकोबार द्वीपसमूह से संग्रहित किया गया है, जो इस क्षेत्र के घास फ्लोरा के लिए एक नवीन वंशपरक अभिलेख है। प्रस्तुत शोधपत्र में जाति का विवरण, छायाचित्रयुक्त प्लेट एवं सवितरण सूचना प्रदान की गई हैं।

\section{Abstract}

The genus Ottochloa Dandy (O. nodosa (Kunth) Dandy) has been collected for the first time from the Andaman and Nicobar Islands, which forms a new generic record to the grass flora of this region. The present paper provides description, photographic plate and distribution information.

Keywords: Andaman and Nicobar Islands, New Report, Ottochloa, Poaceae

\section{INTRODUCTION}

The genus Ottochloa Dandy (tribe Paniceae, subfamily Panicoideae) comprises 3 species and distributed in west central tropical Africa, tropical and subtropical Asia to northern and eastern Australia (POWO 2019). In India, it is represented by a single species, $O$. nodosa (Kunth) Dandy, and distributed in Andhra Pradesh, Assam, Karnataka, Kerala, Manipur, Meghalaya, Nagaland, Sikkim and Tamil Nadu (Bor 1960; Kabeer \& Nair 2009). This species was not recorded earlier from Andaman and Nicobar Islands (Murugan \& al., 2016). While inventorying the grasses of Andaman and Nicobar Islands, the author has collected a few specimens of an Ottochloa species. A detailed study on the collected specimens and consultation of representative specimens at CAL revealed that the specimens belong to O. nodosa (Kunth) Dandy. Thorough perusal of relevant literature (Bor 1960; Murugan \& al., 2016) suggests that this genus was not reported from Andaman and Nicobar Islands earlier thus forms a new generic record to the grass flora of the Islands.

\section{TAXONOMIC TREATMENT}

Ottochloa nodosa (Kunth) Dandy in J. Bot. 69: 55. 1931; Bor, Grasses, Burma, Ceylon, India \& Pakistan: 318. 960; Karthik. \& al., Fl. Ind. Enum. Monocot.: 241. 1981. Panicum nodosum Kunth, Enum. Pl. 1: 97. 1833: Hook.f., Fl. Brit. India 7: 43. 1896.

Annual or perennial. Culms $24-40 \mathrm{~cm}$ long, 


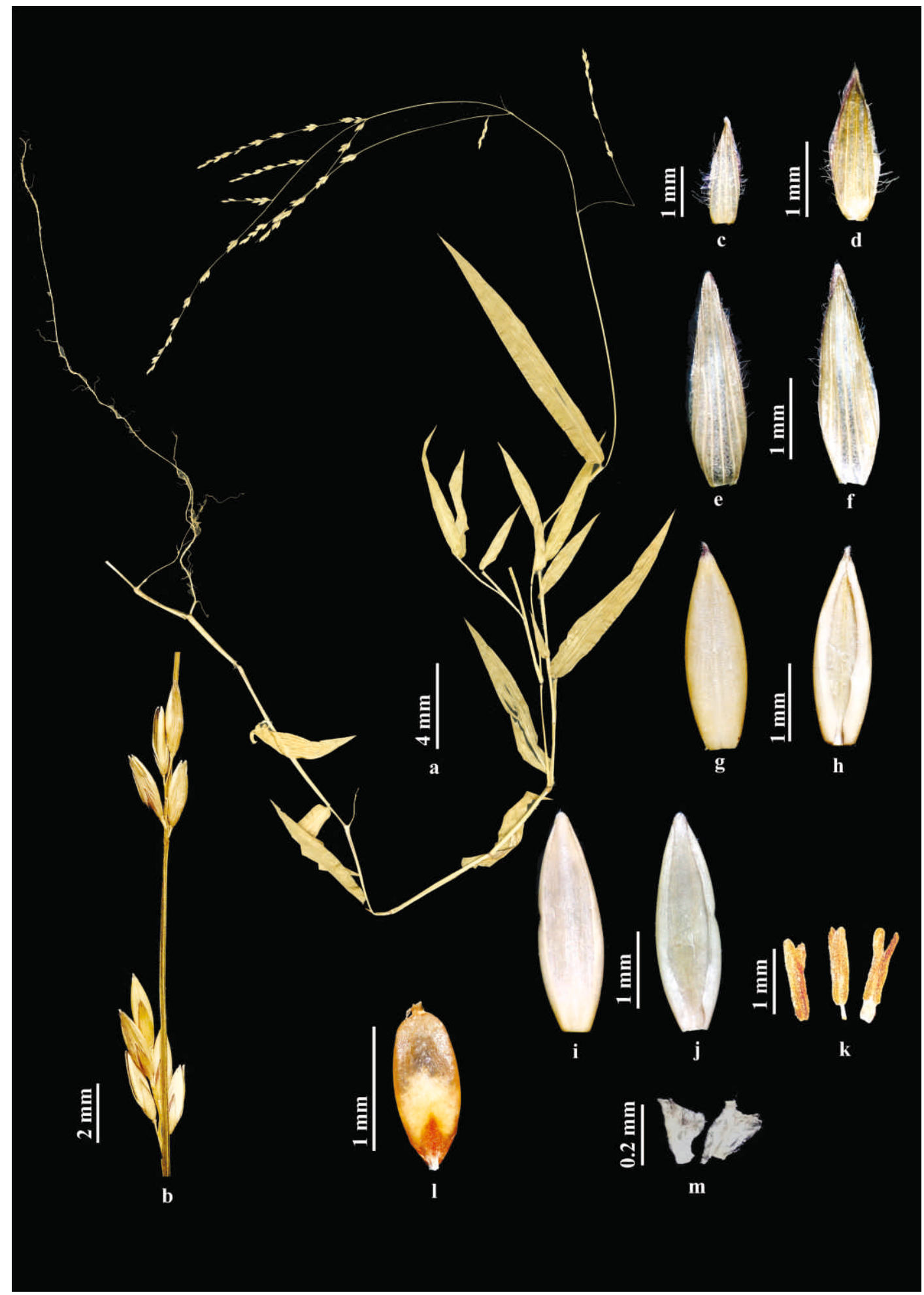

Ottochloa nodosa (Kunth) Dandy: a. Habit; b. Part of inflorescence; c. Lower glume (Dorsal); d. Upper glume (Ventral); e. Lower lemma (Dorsal); f. Lower lemma (Ventral); g. Upper lemma (Dorsal); h. Upper lemma (Ventral); i. Palea (Dorsal); j. Palea (Ventral); k. Stamens; 1. Caryopsis; m. Lodicules. 
stoloniferous, geniculate; nodes glabrous, rooting at lower nodes; internodes $3-5 \mathrm{~cm}$ long, sparsely hairy on one side. Leaf blades 6-12 $\times 1-1.5 \mathrm{~cm}$, lanceolate, apex acute, base asymmetrical with few minute hairs; dorsal surface with 1-3 mm long hairs on lower part; margins serrulate, $0.4-1.5 \mathrm{~mm}$ long bulbous-based hairs on lower part of margins; ligule membranous, obtuse, 0.3-0.4 mm high; leaf sheath $2.5-6 \mathrm{~cm}$ long, densely hairy near margins, bulbous-based hairs one side of margin only. Inflorescence panicle; peduncles 6-14 cm long, glabrous; rachilla triquetrous, ridges scabrid. Spikelets $2-6$ together, $3-4 \times c$. $1 \mathrm{~mm}$, lanceolate, apex acute, nerves light green and prominent. Pedicels $0.8-2.5 \mathrm{~mm}$ long, ridges denticulate, tip cup-shaped. Lower glume 1.3-1.5 $\times 0.4-$ $0.5 \mathrm{~mm}$, lanceolate, apex acute, chartaceous, 5-nerved, obscure near margins, dorsal surface with bulbousbased hair near margins, purple to light green near margins, margins ciliolate or absent. Upper glume 1.9$2.1 \times 0.6-0.7 \mathrm{~mm}$, lanceolate, apex acute, chartaceous, prominently 7 or 8-nerved, lateral nerves from base to middle sometimes, light green, purple on one marginal side, dorsal surface near margins with bulbous-based hair, margins ciliolate, infolded near base. Florets 2; lower barren; upper bisexual. Lower lemma 2.8-3.2 $\times$ $0.7-0.9 \mathrm{~mm}$, apex acute, chartaceous, prominently 7 or 8 -nerved, light green, margins ciliate, slightly infolded near base. Lower palea absent. Upper lemma 3-3.2 $\times$ 0.8-0.9 mm, elliptic-lanceolate, apex mucronate and sparsely hairy, cartilaginous, prominently 5 -nerved, rugose, margins ciliolate, infolded. Palea $2.8-3 \times c .0 .9$ $\mathrm{mm}$, elliptic-lanceolate, apex obtuse, cartilaginous, keeled; keels 2, winged, denticulate, rugose between keels, glabrous between margins to keels, margins ciliolate, infolded. Stamens 3; filaments $0.3-0.4 \mathrm{~mm}$ long, hyaline; anthers $1.3-1.4 \times 0.2-0.3 \mathrm{~mm}$, reddishyellow. Ovary $0.3-0.4 \mathrm{~mm}$ long, elliptic-oblong; style $0.8-0.9 \mathrm{~mm}$ long, hyaline to purple; stigmas $2,1-1.1$ mm long, plumose, purple. Lodicules 2 , membranous. Caryopsis c. $1.4 \times 0.5 \mathrm{~mm}$, oblanceolate to elliptic, light reddish-yellow.

Flowering \& Fruiting: June-December.

Habitat \& Ecology: The species was observed growing near the agriculture field of Syzygium aromaticum (L.)
Merr. \& L.M. Perry and common associates are Apluda mutica L. and Chrysopogon aciculatus (Retz.) Trin.

Distribution: India (Andaman and Nicobar Islands, Andhra Pradesh, Assam, Karnataka, Kerala, Manipur, Meghalaya, Nagaland, Sikkim and Tamil Nadu); Indonesia to northern Australia, Myanmar, Sri Lanka, Malaysia to Philippines, and Africa.

Specimen examined: INDIA: Andaman and Nicobar Islands, South Andaman, Haddo, $11^{\circ} 40^{\prime} 38.61^{\prime \prime} \mathrm{N}$, 92 43'39.32" E, 05.08.2019, Reshma Lakra 86468 (CAL).

\section{ACKNOWLEDGEMENTS}

We are thankful to the Director, Botanical Survey of India for facilities and encouragements. We extend our thanks to the Department of Forests, Andaman and Nicobar Islands for co-operation. We are also thankful to Dr. Kothareddy Prasad for his view and suggestions.

\section{REFERENCES}

BOR N.L. 1960. The Grasses of Burma, Ceylon, India and Pakistan. Pergamon Press London.

KABEER A.A. AND V.J. NAIR 2010. Flora of Tamil Nadu Grasses. Botanical Survey of India, Coimbatore, Pp. 365-366.

MURUGAN C., S. PRABHU, R. SATHIYASEELAN, AND R.P. PANDEY 2016. A Checklist of Plants of Andaman and Nicobar Islands. (edited by SINGH P. AND W. ARISDASON). ENVIS Centre on Floral Diversity, Botanical Survey of India, Howrah. Published on the Internet: http://www. bsienvis. nic. in/Database/ Checklist of Andaman-Nicobar-Islands_24427. aspx (Retrieved on 25 October. 2020).

POWO 2019. Plants of the World Online. Facilitated by the Royal Botanic Gardens, Kew. Published on the Internet; http://www.plants of the world online.org/ Retrieved 25 October 2020. 